\title{
Public opinion toward the European Union in Georgia
}

Müller, Martin

\begin{abstract}
Georgia's association with the EU has become closer in recent years through foreign policy instruments including the European Neighborhood Policy, the Eastern Partnership, and the Black Sea Synergy. Against the background of this increasing formal cooperation, public opinion toward the European Union in Georgia is examined on the basis of a nationally representative survey conducted in 2009. Regression modeling is used to relate attitudes toward the EU to explanatory factors including support for continued European integration, expectations of benefits from Europeanization, political beliefs, perceptions of national security and territorial integrity, and attitudes toward Russia
\end{abstract}

DOI: https://doi.org/10.2747/1060-586X.27.1.64

Posted at the Zurich Open Repository and Archive, University of Zurich ZORA URL: https://doi.org/10.5167/uzh-78836

Journal Article

Published Version

Originally published at:

Müller, Martin (2011). Public opinion toward the European Union in Georgia. Post-Soviet Affairs, 27(1):64-92.

DOI: https://doi.org/10.2747/1060-586X.27.1.64 


\title{
Public Opinion Toward the European Union in Georgia
}

\author{
Martin Müller ${ }^{1}$
}

\begin{abstract}
Georgia's association with the EU has become closer in recent years through foreign policy instruments including the European Neighborhood Policy, the Eastern Partnership, and the Black Sea Synergy. Against the background of this increasing formal cooperation, public opinion toward the European Union in Georgia is examined on the basis of a nationally representative survey conducted in 2009. Regression modeling is used to relate attitudes toward the EU to explanatory factors including support for continued European integration, expectations of benefits from Europeanization, political beliefs, perceptions of national security and territorial integrity, and attitudes toward Russia.
\end{abstract}

M ass public protest in the wake of rigged parliamentary elections in Georgia ousted President Eduard Shevardnadze in November 2003 in what has since become known as the Rose Revolution. In a landslide victory, Western-educated Mikheil Saakashvili and his guard of young reformers were swept into power in the ensuing presidential elections at the beginning of 2004. This political sea change accelerated Georgia's orientation toward Europe. During his inaugural address in January 2004, Saakashvili had the banner of the European Union raised alongside the Georgian flag and declared:

[the European] flag is Georgia's flag as well, as far as it embodies our civilization, our culture, the essence of our history and perspective, and our vision for the future of Georgia.... Georgia is not just a European country, but one of the most ancient European countries.... Our steady course is toward European integration.

\footnotetext{
${ }^{1}$ Assistant Professor for Cultures, Institutions, and Markets at the University of St. Gallen in Switzerland. The author would like to thank the Caucasus Research Resource Center (CRRC) and Hans Gutbrod for providing the dataset and comments on this article.
} 
It is time Europe finally saw and valued Georgia and took steps toward us (Saakashvili, 2004).

The first of several "color" revolutions in the post-Soviet states paved the way for far-reaching reforms strengthening human rights, democracy, the rule of law, and the business and investment climate, which made Georgia the fastest-reforming country in the world in 2006, according to the World Bank. Considered "no more than a footnote" (Freizer, 2004) in the EU's foreign policy until the early 2000s, Georgia made a big leap in formal integration with the European Union through the adoption of the European Neighbourhood Policy (ENP) in 2004 and the Eastern Partnership in 2009. European leaders also played a key role in conflict resolution in the South Ossetian war and the EU brokered a truce between Georgia and Russia under the French presidency (Whitman and Wolff, 2010).

Given Georgia's ever closer formal association with the European Union and its strong foreign policy priority of European integration, it appears warranted to ask whether public opinion justifies this policy vector or whether it is an elite project, pushed by a Western-oriented president, which lacks broad public support. Public opinion toward Europe and the European Union in Georgia is not well understood, however, primarily due to a lack of data. Georgia is not included in the New Europe Barometer and New Russia Barometer surveys of the Centre for the Study of Public Policy at the University of Aberdeen in Scotland, which represents the richest source of data available on public opinion toward Europe in the post-Soviet space (see, for example, Munro, 2007; Rose and Munro, 2008). The last comprehensive assessment of public opinion dates back to the surveys of the Central and Eastern Eurobarometer from 1994 to 1998. Since that time the political, social, and economic landscape in Georgia has undergone profound changes, the most incisive events being the Rose Revolution and the war in South Ossetia in August 2008. The present study is based on a representative public opinion poll of the Georgian population in August 2009 and has two aims:

1. to provide descriptive data about different aspects of the perception of the European Union in Georgia;

2. to relate attitudes toward the EU to explanatory factors using a logistic regression model.

In so doing, it seeks to provide a much-needed analysis for decisionmaking, based on empirical data, that helps understand public opinion toward the European Union in Georgia and can contribute to the refinement of integration strategies.

\section{COMING CLOSER TO EUROPE: GEORGIA AND THE EU}

The European Union and Georgia look back onto a history of cooperation starting with Georgia's independence in 1991 (see Table 1). Initially, 
EU support concentrated primarily on basic humanitarian assistance and food aid in a country riven by violent conflict: from 1992 to 1997, Georgia suffered through two separatist conflicts and two brief civil wars (Cornell, 2001). Toward the end of the 1990s, EU aid shifted to technical cooperation, aimed at facilitating Georgia's economic and social development under the TACIS (Technical Assistance for the Commonwealth of Independent States) program. In the period from 1992 to 2006, grants from the EU to Georgia amounted to EUR 505 million, of which EUR 112 million were disbursed under TACIS (European Union External Action, 2010). Only at the end of the 1990s, however, did the ratification of the Partnership and Cooperation Agreement (PCA) provide a basic legal framework for wideranging cooperation that sought to advance democratic principles, the rule of law, human rights, and a market-oriented economy in Georgia.

Based on the Partnership and Cooperation Agreement (PCA), the ENP was expanded on June 14, 2004 to the countries of the South Caucasus. The ENP aims to share the benefits of EU enlargement in 2004 with adjacent countries and avoid the emergence of new dividing lines between the EU and its neighbors (Gänzle, 2009; for critical assessments of the ENP, see Browning and Christou, 2010; Kostadinova, 2009; Franke et al., 2010). In order to fulfill this mission, the EU and Georgia adopted the Action Plan and the National Indicative Programme in November 2006, which provided the ENP with a concrete agenda (see EU-Georgia Cooperation Council, 2006; European Commission, 2006; European Neighbourhood and Partnership Instrument, 2006). Moving beyond cooperation toward integration, the National Indicative Programme defines priority areas and objectives for the implementation of the Action Plan and is allocated a budget of EUR 120 million from 2007 to 2010. The National Indicative Programme marks the first time that cooperation between the EU and Georgia is embedded in a coherent international framework that specifies concrete goals. The time periods of four years, however, are too short to allow progress toward those goals to materialize. Not surprisingly, the tentative mid-term review in 2009 noted that an assessment of the impact of the National Indicative Programme proved difficult, since none of the projects started in 2007 had been completed (European Neighbourhood and Partnership Instrument, 2009).

The final two pieces in the treaty mosaic that has come to bind together the EU and Georgia in the past years are regional complements to the ENP in Eastern Europe: the Black Sea Synergy, launched in April 2007, and the Eastern Partnership, launched in May 2009. Through the Black Sea Synergy the EU seeks to enhance regional cooperation in a number of key sectors between countries in the so-called Wider Black Sea region, which comprises Armenia, Azerbaijan, Georgia, Moldova, Russia, Turkey, and Ukraine. No additional funds are disbursed under this regional cooperation agreement, which aims at coordinating different regional initiatives through so-called sector partnerships in which joint projects are developed between partners (see Commission of the European Communities, 2007). 
Table 1. Timeline of Important Events in Georgia's Relationship with the European Union since 1999a

\begin{tabular}{|c|c|c|}
\hline Time & Keyword & Details \\
\hline April 1999 & $\begin{array}{l}\text { Council of } \\
\text { Europe }\end{array}$ & Georgia becomes a member of the Council of Europe \\
\hline July 1999 & $\begin{array}{l}\text { Partnership and } \\
\text { Cooperation } \\
\text { Agreement } \\
\text { (PCA) }\end{array}$ & $\begin{array}{l}\text { The PCA between the EU and Georgia enters into force, } \\
\text { establishing the scope for a wide-ranging cooperation } \\
\text { with the following objectives: } \\
\text { - increasing political dialogue } \\
\text { - consolidating democracy in Georgia } \\
\text { - developing a market economy in Georgia } \\
\text { - promoting trade and investment }\end{array}$ \\
\hline $\begin{array}{l}\text { November } \\
2003\end{array}$ & Rose Revolution & $\begin{array}{l}\text { Mass protest leads to the annulment of parliamentary } \\
\text { elections and brings Mikheil Saakashvili to power. }\end{array}$ \\
\hline May 2004 & $\begin{array}{l}\text { European } \\
\text { Neighbour- } \\
\text { hood Policy } \\
\text { (ENP) }\end{array}$ & $\begin{array}{l}\text { ENP includes the EU's eastern and southern neighbors. } \\
\text { It aims to deepen cooperation between the EU and its } \\
\text { neighbors and avoid the emergence of dividing lines } \\
\text { after the } 2004 \text { enlargement }\end{array}$ \\
\hline $\begin{array}{l}\text { November } \\
2006\end{array}$ & Action Plan & $\begin{array}{l}\text { The Action Plan follows up on the ENP and sets out a } \\
\text { general agenda for eight priority areas: } \\
\text { 1. the rule of law, democratic institutions, and human } \\
\text { rights } \\
\text { 2. business and investment climate } \\
\text { 3. economic and sustainable development and pov- } \\
\text { erty reduction } \\
\text { 4. cooperation in the fields of justice, freedom, and } \\
\text { security } \\
\text { 5. regional cooperation } \\
\text { 6. peaceful resolution of internal conflicts } \\
\text { 7. cooperation on foreign and security policy } \\
\text { 8. transport and energy }\end{array}$ \\
\hline $\begin{array}{l}\text { November } \\
2006\end{array}$ & $\begin{array}{l}\text { European } \\
\text { Neighbour- } \\
\text { hood and } \\
\text { Partnership } \\
\text { Instrument } \\
\text { (ENPI), } \\
\text { National } \\
\text { Indicative } \\
\text { Programme } \\
\text { 2007-2010 }\end{array}$ & $\begin{array}{l}\text { The ENPI is the financial instrument for implementa- } \\
\text { tion of the Action Plan. Every country has a National } \\
\text { Indicative Programme that specifies goals, indicators, } \\
\text { and budgets for priority areas on the basis of the } \\
\text { Action Plan. Georgia has four priority areas: } \\
\text { 1. support for democratic development, the rule of } \\
\text { law, and governance } \\
\text { 2. support for economic development } \\
\text { 3. support for poverty reduction and social reforms } \\
\text { 4. support for peaceful settlement of Georgia's inter- } \\
\text { nal conflicts } \\
\text { Total budget for Georgia: EUR } 120 \text { million }\end{array}$ \\
\hline April 2007 & $\begin{array}{l}\text { Black Sea } \\
\text { Synergy }\end{array}$ & $\begin{array}{l}\text { A regional initiative for coordinated action at the } \\
\text { regional level in key sectors such as energy, transport, } \\
\text { environment, mobility, and security. }\end{array}$ \\
\hline
\end{tabular}


Table 1. continued

\begin{tabular}{|c|c|c|}
\hline Time & Keyword & Details \\
\hline August 2008 & $\begin{array}{l}\text { South Ossetia } \\
\text { War }\end{array}$ & $\begin{array}{l}\text { Georgia and Russia clash in a military confrontation } \\
\text { over the status of South Ossetia }\end{array}$ \\
\hline May 2009 & $\begin{array}{l}\text { Eastern Partner- } \\
\text { ship (EaP) }\end{array}$ & $\begin{array}{l}\text { A specific Eastern dimension of the ENP, comprising } \\
\text { Armenia, Azerbaijan, Belarus, Georgia, Moldova, } \\
\text { and Ukraine. The EaP allows for a deeper integration } \\
\text { in the areas of institution building, visa agreements, } \\
\text { free trade, energy security, and regional develop- } \\
\text { ment. It provides additional funds of EUR } 600 \\
\text { million from } 2010 \text { to } 2013 \text {. }\end{array}$ \\
\hline
\end{tabular}

a Sources: Commission of the European Communities (2007); EU-Georgia Cooperation Council (2006); European Commission (2006); European Neighbourhood and Partnership Instrument (2006); European Commission (2009).

In contrast to the Black Sea Synergy, the Eastern Partnership aims to bring the participating countries closer to the EU, yet "without prejudice to individual countries' aspirations for their future relationship with the EU" (Commission of the European Communities, 2008, p. 2). The Eastern Partnership started as an initiative of Poland and Sweden and initially met with considerable reservations from other EU member states. It was only after the war in South Ossetia that the project gained sufficient momentum and the European Commission received the mandate for its implementation (Halbach, 2008). With a modest budget allocation of EUR 600 million for the period from 2010 to 2013, the program has scaled down its ambitions considerably compared to earlier drafts. For Georgia, the Eastern Partnership means additional funds for integration and a renewed commitment on the part of the EU to stand in for regional stability. In its flexible geometry, the Partnership leaves it up to the participating countries to choose the pace of association and offers new contractual relations in exchange for political and economic reform. This gives Georgia an incentive for comprehensive reform and the flexibility to embark on a fast-track path of association with the EU, even though the Eastern Partnership does not imply any substantive movement toward EU membership.

This measure of tighter association, however, runs the danger of deepening the existing chasm with Russia and fueling tensions in an already difficult relationship (see Lapidus, 2007). If the Eastern Partnership becomes an alternative to the Commonwealth of Independent States (CIS) in regional integration and a way of establishing an energy transit corridor from Central Asia and the Caspian that goes around Russia, Russia may well interpret this as an attempt to undermine its influence in the South Caucasus (Gogolashvili, 2009; Sergunin, 2010). The Russian Foreign Minister, Sergey Lavrov, thus condemned the Eastern Partnership as a return to geopolitical competition: "We are accused of having spheres of 
influence. But what is the Eastern Partnership, if not an attempt to extend the EU's sphere of influence, including to Belarus?" (Pop, 2009).

The increasing formal association with the EU corresponds to Georgia's foreign policy strategy: integration into European and Euro-Atlantic security, political, and economic structures is the highest priority on the country's external agenda, with EU membership being the principal longterm foreign policy goal (Gogolashvili, 2009; Papava and Tokmazishvili, 2006). In Georgia, unlike Armenia and Azerbaijan, which try to balance relations with Russia and the EU, both the ruling party and the opposition are unambiguous about the country's pro-European choice (Cornell and Nilsson, 2009). This agenda has found a fervent supporter in President Saakashvili, who has steered the country closer toward the European Union since his election in 2004. Papava and Tokmazishvili state:

[T]he hope of EU membership has been a significant catalyst for change in Georgian society. The vision of joining a larger Europe without barriers has motivated the government to transform the country's economy and deepen economic and political integration during the pre-application period (2006, p. 26).

Although the EU does not plan to extend membership perspectives to the South Caucasus anytime soon, the new administration implemented reforms to work toward meeting the criteria for potential accession (Gogolashvili, 2009). It set out to promote economic growth and improve the investment climate, root out corruption, build new infrastructure, strengthen state power, and align Georgian legislation with European principles. These reforms exemplify the soft normative power through which the EU has been able to support democratization and civil liberties even beyond its borders (Cameron, 2007).

The effect of the war in South Ossetia on public opinion toward the EU also should not be underestimated. Occasioned by the war, EU Foreign Commissioner Benita Ferrero-Waldner stressed the importance of establishing closer bonds with Europe's eastern neighbors as a "strategic imperative" of EU foreign policy (Cornell and Nilsson, 2009; Halbach, 2008). The conflict enabled the EU to demonstrate its capacity as an international political actor. For the first time, it was not the United States but Europe that brokered a peace agreement for a conflict in the European neighborhood. Even though the blame for the outbreak of the war was largely laid on President Saakashvili, the EU was quick to organize a joint donor conference and procure aid money to assist Georgia's recovery. This is a marked change from the Union's earlier, passive role in the territorial conflicts in the South Caucasus (Coppieters, 2007; Halbach, 2007) and has, as one commentator puts it, the potential to raise EU credibility in Georgian official and non-official circles.

The EU is now perceived more as a power that is able to [guarantee] and interested in guaranteeing democratic freedoms, the 
sovereign rights of countries, peace and stability (Gogolashvili, 2009, p. 104).

On the other hand, however, the war in South Ossetia might have long-lasting negative impacts on the perception of the EU. In Azerbaijan, Valiyev (2009) observes, that the war led to a decline in sympathy for the EU and its model of liberal democracy vis-à-vis the Moscow-backed sovereign democracy. In Georgia, the conflict had significant repercussions on social and political reforms and dealt a blow to the fragile economy. Economic growth became sluggish, and from a growth rate of 12.3 percent in 2007, the country went to 2.3 percent in 2008 and contractd by 4.0 percent in 2009 (IMF, 2010). Despite Saakashvili's announcement of a "Second Rose Revolution" in his address to the United Nations General Assembly in September 2008, many of the ambitious political reform projects were bogged down or reversed. Major deficiencies concerning media freedom, the judicial system, and the transparency of elections remained unresolved (Welt, 2009). Widespread dissatisfaction with the performance of the Saakashvili administration led to the polarization of domestic politics and an unprecedented strengthening of opposition forces, culminating in public protests on April 9, 2009 that pressed for the resignation of the president (Cornell and Nilsson, 2009). Since Georgia's European orientation is one of the priority projects of Saakashvili and his United National Movement party (UNM), public opinion toward the EU may be sensitive to the perceived performance of the ruling powers.

\section{MODELING ATTITUDE TOWARD THE EU}

While the commitment of the Georgian elites to a European course is frequently reiterated, little is known about the orientation of the general public toward the EU. Responding to the need for substantive analysis, the present study examines Georgian public opinion toward the EU and its drivers. It is based on a nationally representative survey, conducted in August 2009, which resulted in 1886 full interviews. This section will lay out the steps for building a regression model to predict attitudes toward the EU in Georgia. The Appendix contains a detailed description of each variable for replication purposes as well as details on the survey methodology, data preparation, and analysis. The dependent variable in our analysis was derived from the survey question "What is your general perception of the EU?" Respondents were able to choose on a five-point scale ranging from 1 (= very negative) to 5 (= very positive). For the regression model, attitude was recoded into a dichotomous variable in which a proEuropean attitude was represented by the two highest points (positive and very positive) on the scale. A review of previous studies on attitudes toward the European Union in post-socialist countries yielded seven sets of explanatory variables as predictors for pro-European attitude. In order to isolate the contribution of each set of predictors to explaining a 
pro-European attitude, a regression model was specified in which sets of predictors were added stepwise (Table 4).

Sociocultural background. Age is commonly found to be the strongest predictor of attitudes toward the European Union among sociocultural variables, with older people holding a more negative opinion about the European Union (Jacobs and Pollack, 2006). Educational achievement, on the other hand, is a positive predictor in a number of surveys, where higher levels of formal education were associated with more positive attitudes (Caplanova et al., 2004; Munro, 2007; White et al., 2002b). Younger and more educated people are generally thought to be better able to reap the benefits of open borders and a single market and therefore have a more positive disposition (Fligstein, 2008). The effect of gender is less clear. In some instances, men were found to be more likely to adopt a pro-European stance than women (Tucker et al., 2002; White et al., 2002b), whereas White et al. (2008) find, for the case of Russia, that it is women who show a stronger orientation toward Europe.

Ethnicity tends to be an important factor in states with strong minorities, such as the Russian minorities in the Baltic states, who support European integration less than the titular nations because of their bonds to Russia (Whitefield et al., 2006). In Georgia, Azeris (6.5 percent) and Armenians (5.7 percent) represent sizable minorities, while 83.8 percent of the population is ethnic Georgians (Statistical Yearbook of Georgia, 2007). Ethnicity has become a key determinant of identity for many Georgians and non-Georgians alike, particularly in the secessionist conflicts around Abkhazia and South Ossetia (Halbach, 2009) and may therefore be expected to have an impact on the view of Europe. Finally, religion may act as a possible predictor of pro-European attitudes. Spirituality and religion have experienced a rebound after the collapse of the Soviet Union and are an important factor in everyday life after socialism. This notwithstanding, the powerful influence of religion and religiousness on political preferences has remained underexplored in analyses of the European orientation in post-socialist countries (Bruce, 2003).

Economic experience. The economic situation of households has been found to be a strong explanatory variable of support for the European Union. Higher income and a comfortable economic situation are associated with a pro-European orientation (Caplanova et al., 2004; Jacobs and Pollack, 2006). This reflects the underlying hypothesis that winners of the post-socialist transformation toward a market economy endorse further alignment with Western institutions and a continuation of the reform process, since this would benefit their individual situation.

Knowledge. A lack of information about a certain subject often translates into suspicion and reservation. It is therefore a common assumption in studies of attitudes that a higher level of knowledge is connected to a more positive attitude toward a subject. This correlation has been confirmed for support of EU membership and European orientation (White et al., 2002a; White et al., 2008), but has otherwise received little attention in comparable studies. 
Political beliefs. There seems to emerge a consensus in the literature on support for the European Union in post-socialist states that sociocultural and economic variables are poor predictors, when compared to political beliefs and value orientations (Jacobs and Pollack, 2006; White et al., 2008). Partisan choice, as Rohrschneider and Whitefield (2006) claim, is a neglected area of study in this respect and could reveal much about the association of pro-European attitudes with particular political parties. The assumption here is that voters take their cues from parties as a shorthand guide to structuring complex political decisions about new and remote issues (Jacobs and Pollack, 2006). People's expectation about the nature of government may also influence attitudes toward the European Union. Preference for a more paternal style of government with a strong presence of state institutions and preference for state intervention-as is common in many post-socialist states-may conflict with support of the European Union, which embodies a more distant and indirect way of governing based on individual freedom. In a similar vein, the general degree of trust in institutions may be positively correlated with a pro-European orientation, since the European Union appears for most people as an abstract institutional actor. In line with other authors (see Munro, 2007; Whitefield et al., 2006), it is also assumed that satisfaction with the state of democracy in the country is a predictor of positive attitudes. If people perceive democracy to be in good health and working well, support for the European Union, which stands in for democratic values and reforms, will be higher.

Cosmopolitanism. Cosmopolitanism is a set of predictors that measure individuals' openness and exposure to Europe. A number of studies (Rose and Munro, 2008; White et al., 2002a) were able to confirm that a European self-identification and having friends and relatives in the West were positively associated with a pro-European attitude in Russia. In addition, other analyses have confirmed the positive effect of exposure to Europe through journeys or periods of residency for studying or working (White et al., 2002a; White et al., 2002b). Foreign language ability may be another factor that contributes to greater openness toward Europe, since it allows interaction with people from European countries, reading foreign-language literature or watching films, and following current affairs in foreign-language media. In some cases, urban residence had a significant positive effect on attitudes toward Europe (White et al., 2002b; White et al., 2008), although other studies were able to find this effect only for large metropolitan areas and not for smaller cities (Rose and Munro, 2008).

Instrumental gain. A utilitarian position would suggest that a positive assessment of gains from closer association with the European Union is linked to positive attitudes (Jacobs and Pollack, 2006). In contrast to value orientations, instrumental gain refers to the immediate benefits and costs associated with European integration, covering such aspects as economic growth, price stability, freedom of speech, or independent media. Although Rohrschneider and Whitefield (2006, p. 147) maintain that value orientations are of greater importance than instrumental factors in assessing attitudes toward the European Union in Eastern Europe, instrumental cal- 
"I am Georgian and therefore I am European."

In general, what is your perception of the EU?

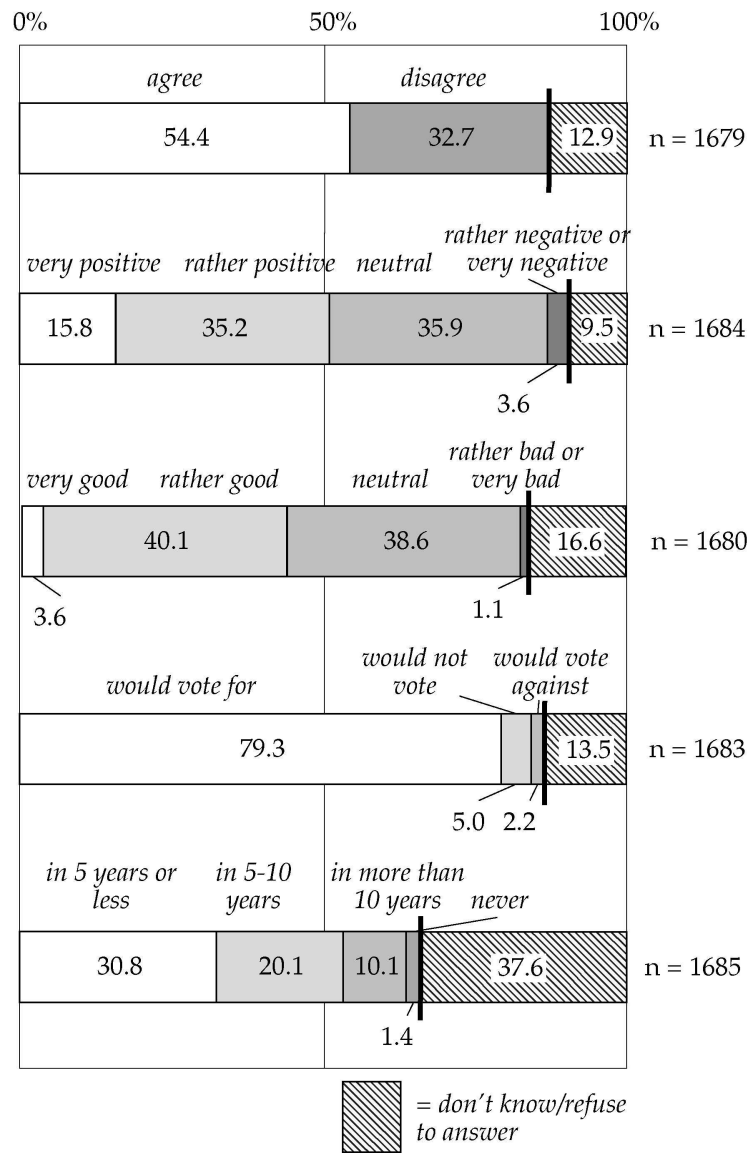

Fig. 1. Perception of the EU and European identity in Georgia (2009).

culations have been found to be reliable predictors in Western European countries (e.g., Hooghe and Marks, 2005) and are therefore included in this study.

Relations with Russia. In order to account for the special situation in Georgia after the conflict in South Ossetia, perception of relations with Russia is included as a set of control variables. In particular, the model controls for the perception of Russia as a threat and for the perceived importance of Russia as Georgia's most important political partner.

\section{RESULTS}

The perception of Europe is highly positive in Georgia. Figure 1 shows that more than five out of 10 Georgians see themselves as culturally European and agree with the statement of the late Prime Minister of 
How important is it for Georgia to strengthen ties with ... $(\mathrm{n}=1676)$
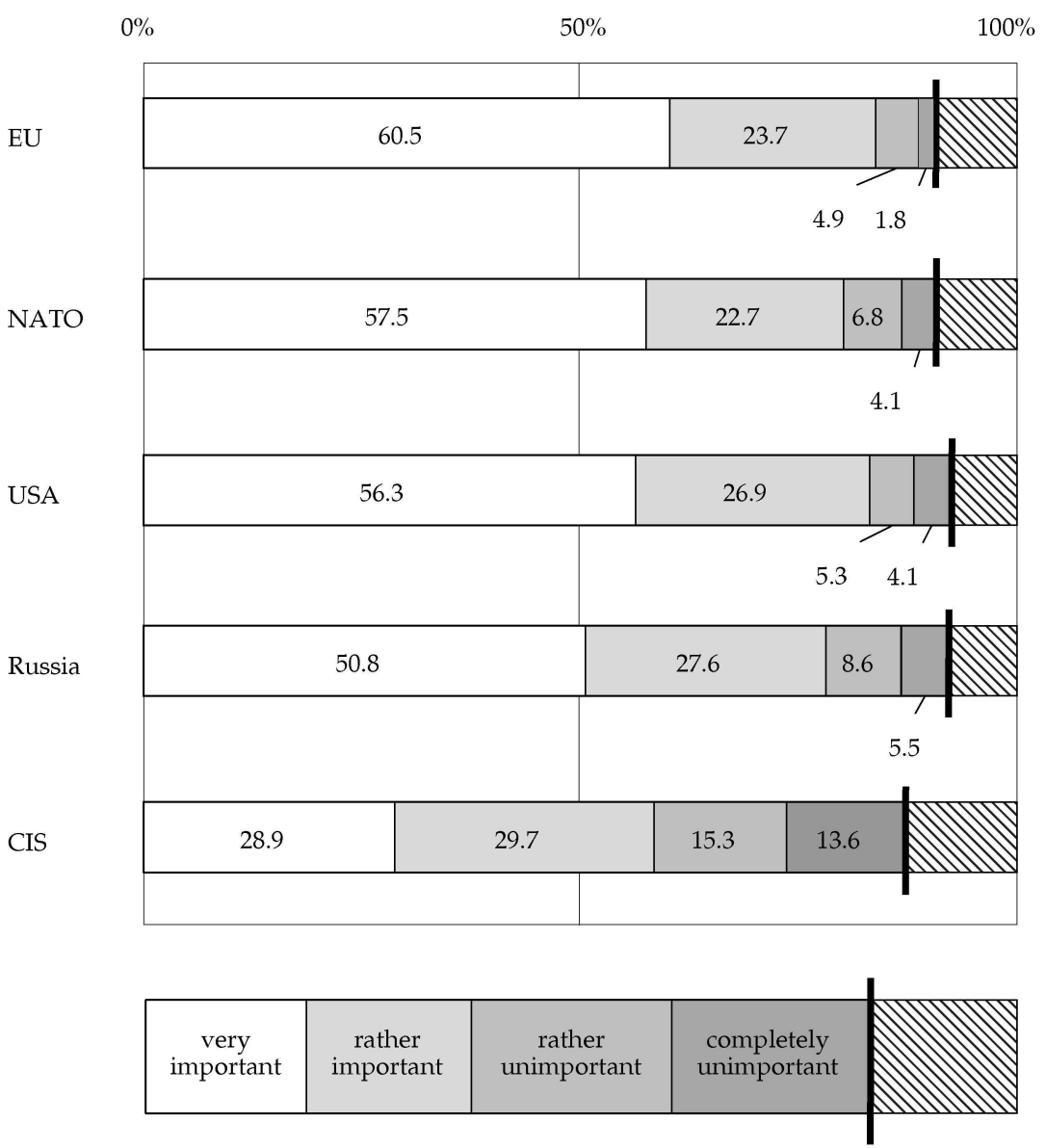

Don't know/refuse to answer

Fig. 2. Rating of Georgia's foreign policy priorities (2009).

Georgia, Zurab Zhvania, in his speech before the Council of Europe in 1999: "I am Georgian and therefore I am European." More than half of the respondents in the sample have a positive attitude toward the European Union, while only 3.6 percent report a negative attitude. Almost four-fifths would vote in favor of EU membership in a hypothetical referendum and the majority adopts a highly optimistic outlook on Georgia's prospects for becoming an EU member in the future: close to one-half of the population believes that Georgia will become an EU member in 10 years or less. 
What are the three most important issues facing Georgia at the moment? $(\mathrm{n}=1673)$

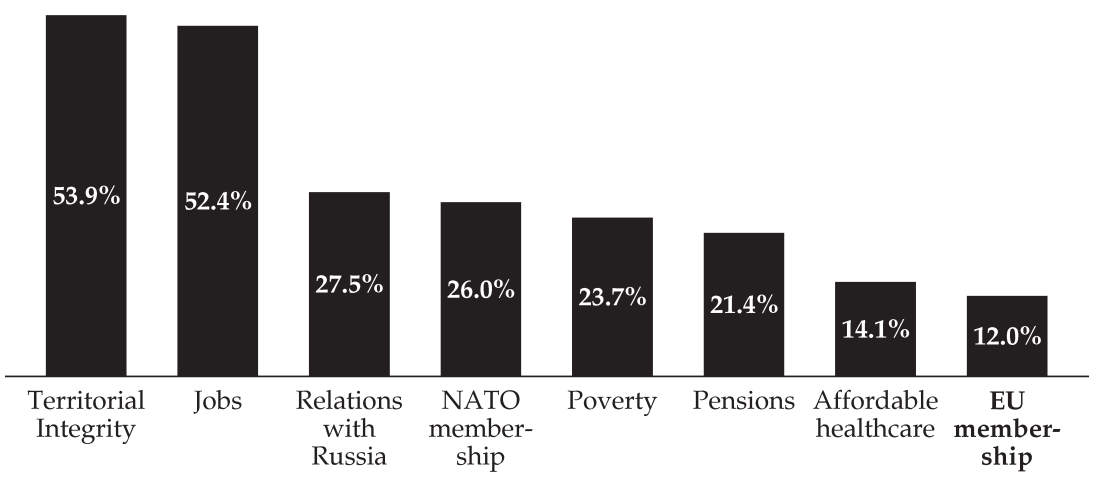

Fig. 3. The most important issues facing Georgia at the moment (2009).

Figure 2 demonstrates that working on a closer association with the EU is seen as paramount for Georgia, with the US and NATO ranking slightly lower in priority. Although orientation toward the post-Soviet space is considerably less popular, it is important to note that strengthening ties with Russia is also rated as important, indicating that a unilateral association with Europe might not be the avenue favored by the majority of the population.

The most pressing issues for the population are not external relations with the EU, however, but territorial integrity and jobs (Figure 3). EU membership is down on rank 8 of the list and considered by only 12 percent to be one of the three most important issues facing Georgia at the moment. Relations with Russia and NATO membership, in contrast, get 28 percent and 26 percent of the vote. While the EU enjoys popularity and a positive image, it is actors like Russia and NATO that seem to have greater significance for Georgia's current situation of territorial instability. National security and territorial integrity, accordingly, lead the list of areas in which Georgians expect the most significant improvements resulting from a potential EU membership (Table 2). Democratic values, such as freedom of speech or fairness of elections, and economic development, such as an increase in jobs or better pensions, trail somewhat behind. The high percentage of respondents indicating that they do not know or refuse to answer suggests, however, that expectations from EU membership might be based more on hopes and speculations than on sound information and knowledge.

Perceptions of the EU vary significantly depending on how Georgians rate the state of democracy in their country (Table 3). Those who perceive Georgia as performing well on the democracy record also hold a significantly more positive opinion of the EU. They are more likely to characterize the EU as a democratic organization promoting peace and 


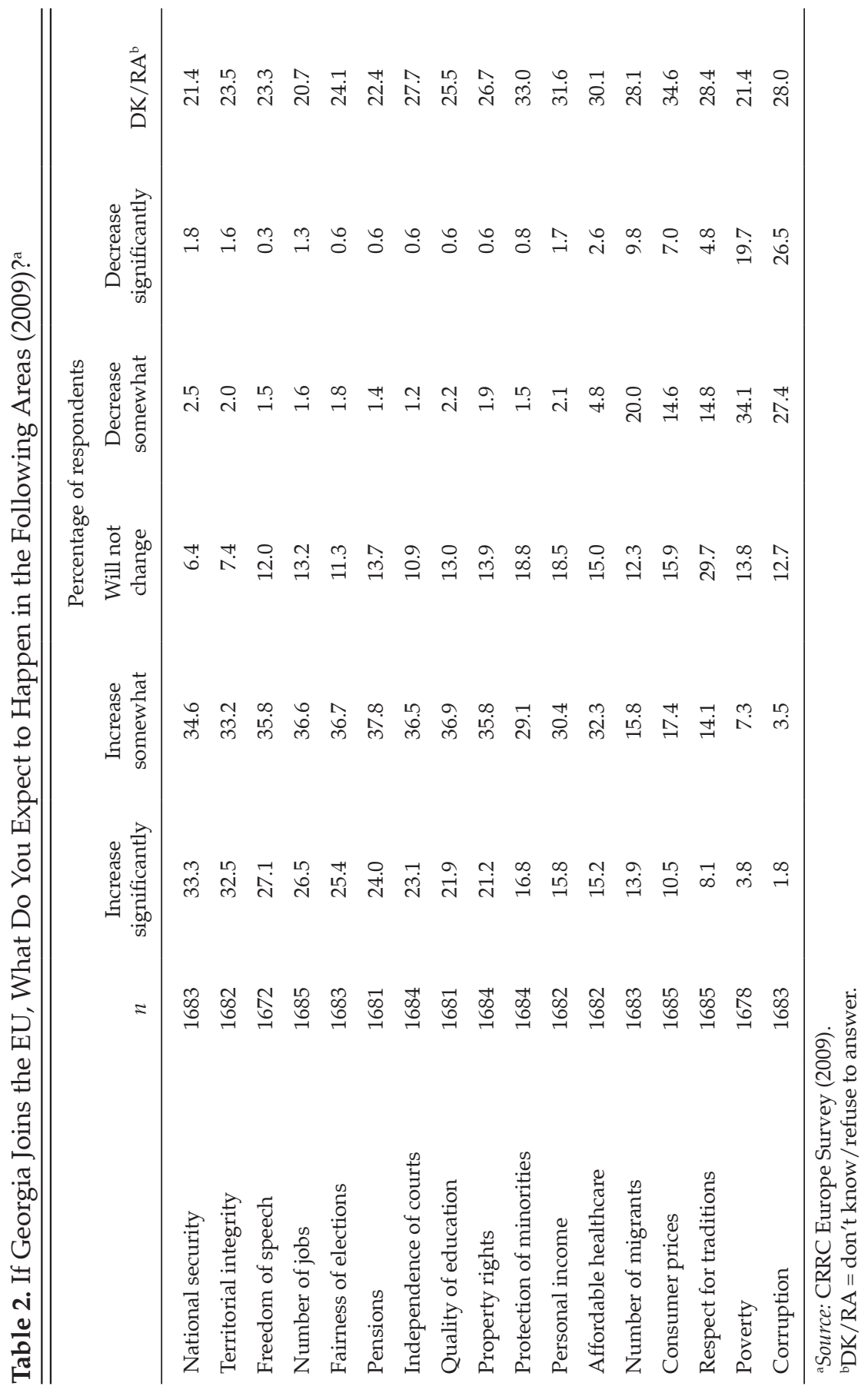




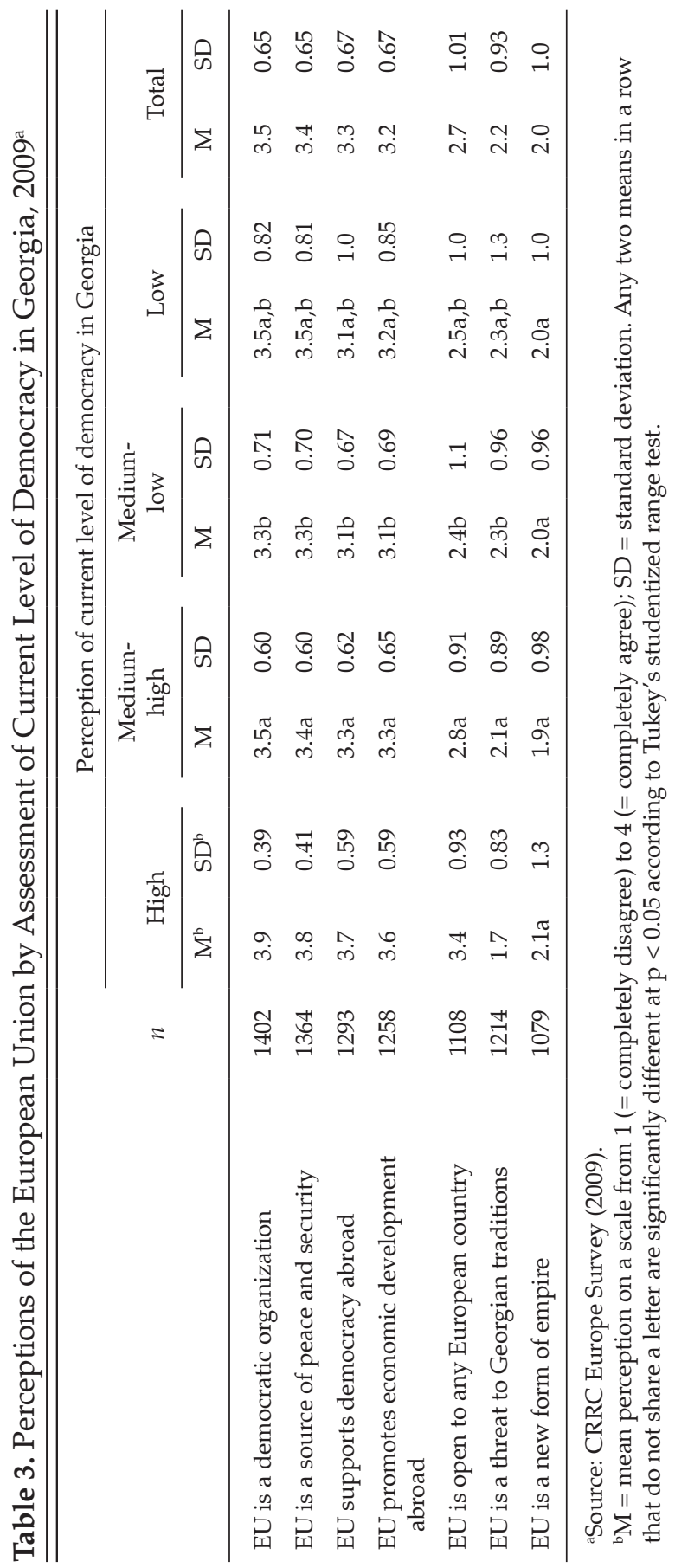


security as well as democratic and economic development abroad. In the same vein, they are also less likely to see the EU as a threat to Georgian traditions. In general, the EU's role in supporting democracy, peace, and economic development is well recognized. There is some doubt, however, whether the EU is willing to accept any European country as a member, as stipulated under article 237 of the 1957 Treaty of Rome for the European Economic Community.

The public profile of the EU in helping to negotiate peace in the war in South Ossetia is rather low. The most important role in ending the conflict is attributed not to the EU but to France as a single actor (31.8 percent of respondents) and then to the US (23.8 percent). Unlike what happened in Azerbaijan (Valiyev, 2009), however, levels of trust even increased following the conflict: whereas in 2007 only 20.0 percent of the Georgian population indicated they fully trusted the EU, this percentage went up to 26.4 percent in 2009 (Caucasus Research Resource Center, 2009).

\section{MODELING A PRO-EUROPEAN ATTITUDE}

Next, we built stepwise regression models to isolate predictors for a pro-European attitude (Table 4). The initial models yield little explanatory value for the standard set of variables relating to sociocultural background and economic experience (Models 1 and 2). Being male and having a higher household expenditure are weakly correlated with a positive attitude toward the EU, but the effect disappears for gender as more variables are included. Adding knowledge about the European Union (Model 3 ) as a predictor does not improve the model.

The most significant improvement occurs with the set of variables reflecting political beliefs (Model 4), increasing Nagelkerke's $R^{2}$ from 0.02 to 0.12 . All four predictors-party preference, preference for a paternal government style, assessment of the current level of democracy, and institutional trust - enter the regression equation below the significance threshold. A preference for Mikheil Saakashvili's party, United National Movement, high institutional trust, and a high rating of the current level of democracy in Georgia are all associated with a pro-European attitude. By contrast, a preference for a paternal style of government is associated with a more negative attitude toward the EU.

Among the predictors measuring cosmopolitanism (Model 5), only European self-identification has a significant positive effect on opinion toward the EU. Direct exposure to Europe via residence, travel, or foreign-language knowledge as well as residence in Tbilisi do not show significant effects. The effect of household expenditure, however, declines, when adding the cosmopolitanism variables, suggesting that well-off population groups have a higher exposure to Europe and, through this direct experience, might develop a more positive attitude.

The single predictor with the largest effect is the indicator measuring instrumental gain through the perceived benefit of joining the EU (Model 6). Instrumental calculations of loss and gain appear to be key factors in 


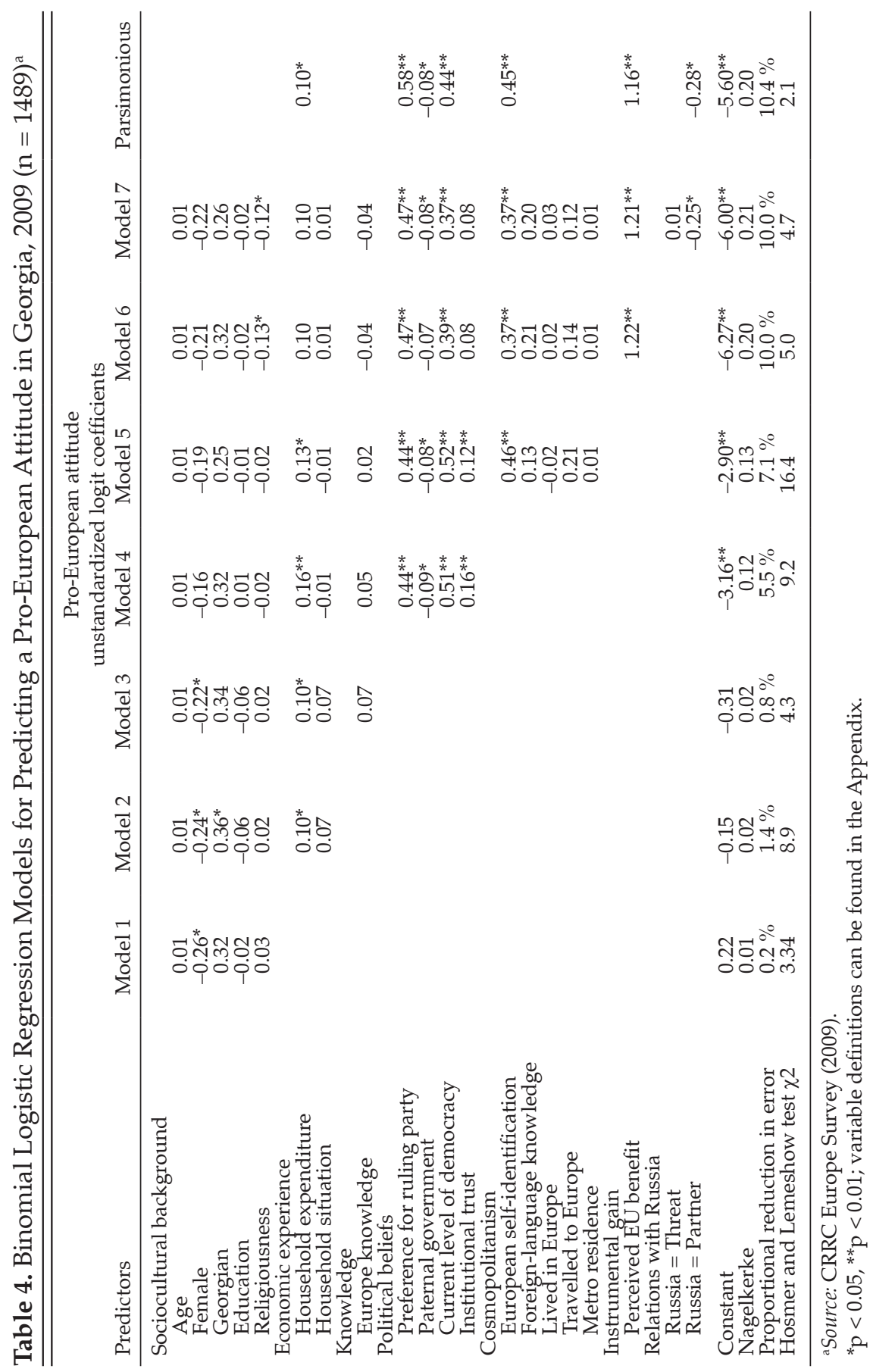




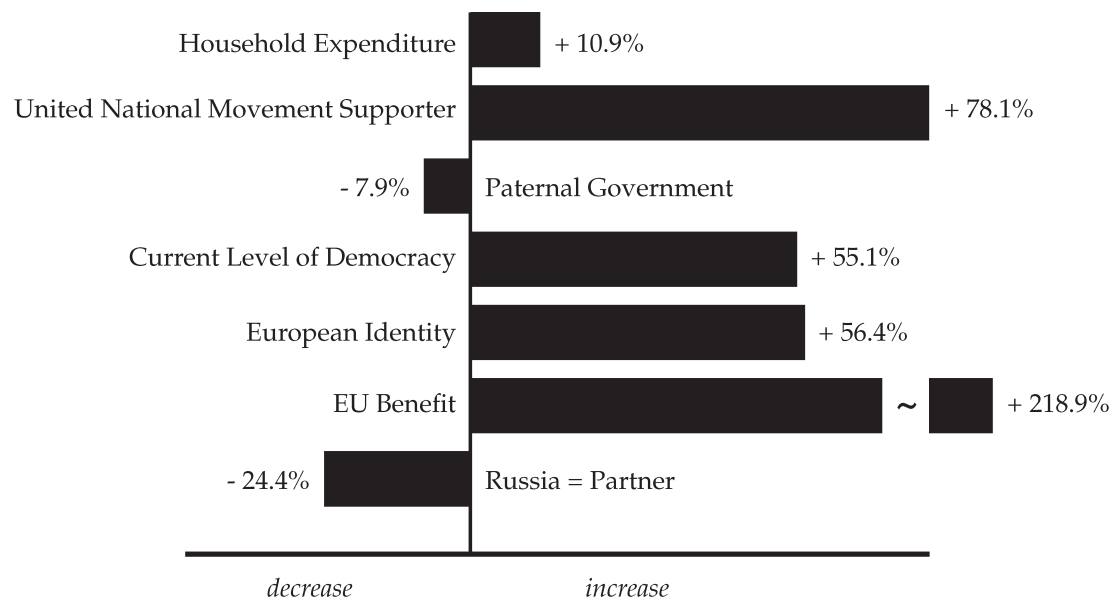

Odds of being pro-European

Fig. 4. Changes in the odds of being pro-European per unit change in significant predictors (parsimonious model).

adopting a position toward the EU: those who expect little or no gain for Georgia from a potential EU membership display significantly more negative attitudes. Finally, controlling for relations with Russia reveals a weak correlation with the position that Russia should be Georgia's most important partner. Advocating close political cooperation has a weak negative impact on opinion toward the EU. No effect is found for the perception of Russia as a threat.

The parsimonious model includes seven significant variables and achieves a 10.4 percent reduction in error versus guessing. Figure 4 shows the effects of the seven predictors on the odds of having a pro-European attitude. Household expenditure, a preference for paternal government, and considering Russia the most important partner have small to moderate effects on the dependent variable. By contrast, perceived benefits from joining the EU, the evaluation of the current level of democracy in Georgia, and being a supporter of the ruling party have a relatively large impact. All signs of coefficients have the direction hypothesized earlier. With a Nagelkerke $R^{2}$ of 0.20 , the proportion of variance explained by our model is in the order of other studies on attitudes toward Europe in postSoviet countries (e.g., Rose and Munro, 2008; White et al., 2002b).

\section{DISCUSSION}

\section{Public Opinion Toward the EU}

Georgia is a special case in terms of public opinion toward the European Union. With more than half of the population identifying as 
European and 77 percent in favor of EU membership, the country dwarfs all other states in the Eastern Partnership with its Euro-enthusiasm-both its neighbors in the South Caucasus (see Svensson and Hon, 2010) and Belarus, Moldova, and Ukraine in Eastern Europe (see White et al., 2008; White et al., 2002b). The war in South Ossetia has only served to reinforce the belief that Georgia's future lies in Europe and not in the post-Soviet space, as it seems to have cemented trust in the European Union. The situation in 2009 presents a marked change compared to the results of the Central and Eastern Eurobarometer in 1996. Then, 51 percent of Georgians believed that the country's future lay with Russia, whereas only 11 percent thought it lay with the European Union. Only 37 percent had a positive perception of the EU (now: 50 percent), whereas 10 percent had a negative perception (now: 4 percent) (European Commission, 1997).

Although strengthening relations with the EU is considered a top priority, in terms of importance for Georgia, the EU ranks behind NATO and Russia. Much of this can be attributed to the precarious territorial situation. National security and territorial integrity are the primary concerns for Georgians at the moment and NATO and Russia are seen as more potent actors with regard to Georgia's territorial interests than the European Union. While closer association with the EU enjoys high popularity, Georgians expect the main effects of a hypothetical membership not in the priority areas of the ENP — internal government and economic reformsbut in ameliorating Georgia's security predicament. There is, therefore, much wishful thinking projected into the partnership with the EU-wishful thinking that exhibits a considerable divergence from what the EU expects from this partnership.

Although closer association with the EU is perceived as a means of safeguarding Georgia's territorial integrity vis-à-vis Russia, a positive opinion toward the EU does not equal a negative opinion toward Russia. On the contrary, Georgians insist on maintaining a good relationship with the neighbor to the north (to compare attitudes toward Russia across Ukraine, see Barrington and Faranda, 2009, pp. 249-251). This is surprising considering the antagonism that characterized high-level relations between the two countries before, during, and after the war in South Ossetia. The general public does not seem to support the black-and-white thinking of the ruling elites but, while favoring a general orientation toward Europe, would prefer to see good neighborly relations with Russia. On the basis of our analysis, the assumption that the relationship with Russia has a strong effect on attitudes toward the EU needs to be reviewed: perceiving Russia as a threat neither has an intimidating effect and reduces support for Western institutions (see Cornell and Nilsson, 2009) nor pushes public opinion even more toward the supposedly safe haven of Europe. Only perceiving Russia as the most important international partner of Georgia is associated with a slight reduction in the odds of having a pro-European orientation. This suggests that the assessment of the role of Russia is perhaps less significant for the attitude toward the EU than one might assume given Russia's looming presence in Georgian politics and that there is little 
evidence of a pro-Russia / pro-Europe divide in Georgia that would polarize public opinion in a similar way as in Ukraine (Munro, 2007).

\section{Drivers of Public Opinion}

What, then, can the drivers of public opinion tell us about the social characteristics of pro-European population groups in Georgia? A proEuropean attitude can be found among those groups who have a household expenditure above average, support the current regime, have a positive assessment of the current level of democracy, and consider themselves European. These tend to be people who do not see Russia as Georgia's main external partner and favor a less paternal style of government. The large pro-European part of the population expects benefits from Europeanization that amount to a modernization of the country, resulting in a more transparent government, freedom of speech, rule of law, and increased opportunities for economic development. This implies that it is the self-perceived winners of a closer association who have a positive attitude toward the EU, whereas those who stand to lose tend to have a more negative attitude.

The above characterization indicates that sociocultural variables have little explanatory value for predicting attitudes toward the EU, and household expenditure, though significant, is only a weak predictor. In this, Georgia is different both from other countries in the post-Soviet space (e.g., White et al., 2008) and from Western European countries, where age, education, occupation, and income act as strong predictors of attitude (Fligstein, 2008; Rohrschneider and Whitefield, 2006). This may be a result of the highly politicized environment in contemporary Georgia in which the influence of basic socioeconomic determinants is overruled by more immediate political orientations. The empirical findings in this article lend support to this hypothesis, given that political beliefs exercise a strong influence on attitudes. Partisan choice, a variable frequently neglected in other studies, has a significant effect which remains even when controlling for other variables. Cue-taking from political parties therefore seems to be very prevalent on top of all other effects.

Despite the widespread cultural identification with Europe among the Georgian population, European identity is not nearly as strong a predictor for a pro-European orientation as the expected gains from EU membership. Public opinion toward the EU is therefore more dependent on the instrumental benefits from closer association than on cultural affinity. This questions the primacy of a cultural explanation, based on the presence or absence of a European identity, for predicting a pro-European attitude. This cultural explanation enjoys popularity in research on public opinion in Western European states, but does not seem to hold in equal measure for Georgia (Checkel and Katzenstein, 2009; Fligstein, 2008; Hooghe and Marks, 2005).

In a similar vein, the case of Georgia presents something of an anomaly, since conventional wisdom suggests that the expected gains from European 
integration will be lower for less-developed states and support for a European course in these states will root more in value orientations rather than in a utilitarian calculus (Jacobs and Pollack, 2006, p. 97; Rohrschneider and Whitefield, 2006, p. 155). The Georgian population believes, however, that the country will reap a considerable benefit from integration into Europe. Considering the almost excessive expectations associated with European integration, it might well be the case that this perception changes as integration continues to deepen. The movement toward establishing a single market stands to fuel concerns with price increases and hasten the exposure of Georgian businesses to European competition. The introduction of EU standards is likely to increase production costs and put pressure on inefficient producers in protected industries. This applies in particular to agriculture and viniculture, which provide employment to more than 50 percent of the Georgian labor force and produce Georgia's major export products. Since agriculture is the most heavily regulated economic sector in the EU, adjustment costs will be considerable and are likely to dampen the optimism for people working within affected industries. Similarly, groups benefitting from nontransparent government structures are also bound to be opposed to the project of political modernization that comes with European integration as it reduces the opportunities of rent-seeking and corruption.

The prevalence of an instrumental assessment of potential gains in driving the assessment of the European Union makes public opinion more directly connected to the perceived performance of integration and less intractable than when based on cultural or value orientations. At the same time, however, it becomes more volatile in case the perception of benefits from integration shifts. Similar to what happened in the Eastern European countries prior to their accession in 2004, the positive public opinion toward the EU might recoil as European integration progresses and overly rosy expectations yield to reality (Rohrschneider and Whitefield, 2006).

\section{CONCLUSION: EU-PHORIA}

euphoria (u-for'e-ah): a feeling of great happiness or well-being, commonly exaggerated and not necessarily well founded (American Heritage Medical Dictionary, 2007).

Georgians are in EUphoria. A vast majority of the population supports a closer alignment of the country with the EU and would vote in favor of accession. President Saakashvili's European course finds broad public support among Georgians, regardless of age, education, ethnicity, or gender. The conflict in South Ossetia and the subsequent strengthening of the domestic opposition movement have done little to shake confidence in Georgia's European choice. Georgians continue to show a remarkable enthusiasm for the European Union, which should give sufficient popular 
backing to the necessary reforms for a closer association of Georgia with the EU in the framework of the European Neighborhood and Partnership Instrument and the Eastern Partnership.

But as with any kind of euphoria, the high hopes placed on the EU might turn out to be ill-founded and make for a sober morning after. Since the process of alignment with the EU is still in its infancy, Georgians seem to see closer association with the EU through rose-colored glasses. Expectations that Georgia will soon become a member of the EU or that the EU might resolve the territorial conflicts in Georgia's favor and restore the country's territorial integrity are overly optimistic and not justified by reality. Moreover, once adjustment costs from European integration start to be felt in the population, this could result in a serious backlash. The large number of people working in agriculture, viniculture, national monopolies, or other protected industries may revise their assessment of benefits from a closer association with the EU.

The analysis in this article demonstrates that the instrumental assessment of potential benefits from EU membership is more important for a positive attitude than cultural identity. Public opinion is therefore dependent on the performance of integration, and disappointment with the benefits of Europeanization may easily revert into resentment. Showing commitment to the goals of the Neighborhood Policy and the Eastern Partnership and delivering on the promises of Europeanization-stability, democracy, economic development, infrastructural improvement-is central for maintaining support for continued integration. Promoting democratic reforms may be a particularly effective way of supporting transformation in Georgia and garnering public approval, since people's positive evaluation of the state of democracy is positively correlated with the perception of the EU. Yet, given the unrealistic expectations from closer association with the European Union, it might prove hard to maintain current levels of support in the future.

Finally, contrary to some expectations, broad public support for the country's European orientation does not mean a turn away from Russia. This is where public opinion exhibits a significant divergence from the position of the government. Georgians would like to see friendly relationships with Russia rather than a prolonged antagonism. This may be surprising considering the recent incursion of Russian armed forces on territory claimed by Georgia and the resultant political and economic turmoil. But centuries of shared history have forged social and economic ties that keep binding the two countries together, and these may be too close to be severed easily. Georgians seem to have an acute awareness that, despite all formal association, the European Union is far and Russia is just around the corner. The EU will be doing Georgians a favor if it keeps-as it has done in the past-Russia's interests in the South Caucasus firmly in sight as it reaches out eastwards, pursuing a strategy of inclusion and balancing rather than of divide and rule. 


\section{REFERENCES}

American Heritage Medical Dictionary. Boston: Houghton Mifflin, 2007.

Barrington, Lowell and Regina Faranda, "Reexamining Region, Ethnicity, and Language in Ukraine," Post-Soviet Affairs, 25, 3:232-256, July-September 2009.

Browning, Christopher S. and George Christou, "The Constitutive Power of Outsiders: The European Neighbourhood Policy and the Eastern Dimension," Political Geography, 29, 2:109-118, February 2010.

Bruce, Steve, Politics and Religion. Cambridge: Polity Press, 2003.

Cameron, David R., "Post-Communist Democracy: The Impact of the European Union," Post-Soviet Affairs, 23, 3:185-217, July-September 2007.

Caplanova, Anetta, Marta Orviska, and John Hudson, "Eastern European Attitudes to Integration with Western Europe," JCMS: Journal of Common Market Studies, 42, 2:271-288, June 2004.

Caucasus Research Resource Center (CRRC), CRRC Data Initiative, Tbilisi, 2009.

Caucasus Research Resource Center (CRRC), CRRC Europe Survey, Tblilisi, 2009.

Checkel, Jeffrey T. and Peter J. Katzenstein, eds., European Identity. Cambridge: Cambridge University Press, 2009.

Commission of the European Communities, "Communication from the Council to the Council and the European Parliament: Black Sea Synergy: A New Regional Cooperation Initiative," Brussels, April 11, 2007.

Commission of the European Communities, "Communication from the Commission to the European Parliament and the Council: Eastern Partnership," Brussels, March 2008.

Coppieters, Bruno, "Dimensionen der Konfliktlösung: Die EU und Georgiens abtrünnige Gebiete," Osteuropa, 57, 11:67-82, 2007.

Cornell, Svante E., Small Nations and Great Powers: A Study of Ethnopolitical Conflict in the Caucasus. Richmond, UK: Curzon, 2001.

Cornell, Svante E. and Niklas Nilsson, "Georgian Politics since the August 2008 War," Demokratizatsiya, 17, 3:251-268, Summer 2009.

EU-Georgia Cooperation Council, "EU-Georgia Action Plan," Brussels, 2006, available at http://ec.europa.eu/environment/enlarg/pdf/enp_action_plan_georgia. pdf.

European Commission, Central and Eastern Eurobarometer 8: Public Opinion and the European Union. Brussels: European Commission, 1997.

European Commission, "European Neighbourhood and Partnership Instrument: Georgia: Country Strategy Paper 2007-2013," Brussels, 2006.

European Commission, "Vademecum on Financing in the Frame of the Eastern Partnership," External Relations Directorate General, European Neighbourhood Policy Directorate, Brussels, December 2009.

European Neighbourhood and Partnership Instrument, "Georgia: National Indicative Programme 2007-2010," Brussels, November 2006.

European Neighbourhood and Partnership Instrument, "Georgia: Initial Concept Note," 2009, Brussels, April 2009.

European Union External Action (European External Action Service/EEAS), "Summary on EU-Georgia relations," Brussels, 2010, available at http:/ / eeas.europa.eu/ georgia/eu_georgia_summary/index_en.htm.

Fligstein, Neil, Euroclash: The EU, European Identity, and the Future of Europe. Oxford: Oxford University Press, 2008. 
Franke, Anja, Andrea Gawrich, Inna Melnykovska, and Rainer Schweikert, "The European Union's Relations with Ukraine and Azerbaijan," Post-Soviet Affairs, 26, 2:149-183, April-June 2010.

Freizer, Sabine, "The Pillars of Georgia's Political Transition," Open Democracy, February 12, 2004, available at www.opendemocracy.net/democracy-caucasus/article_1732.jsp.

Gänzle, Stefan, "EU Governance and the European Neighbourhood Policy: A Framework for Analysis," Europe-Asia Studies, 61, 10:1715-1734, December 2009.

Gogolashvili, Kakha, "The EU and Georgia: The Choice Is in the Context," Europe in Dialogue, 1:92-129, 2009.

Halbach, Uwe, “Eingefrorene Konflikte im Südkaukasus: Probleme und Grenzen der Europäisierung," Osteuropa, 57, 11:83-94, 2007.

Halbach, Uwe, “Rückblick auf den „Fünftage-Krieg“: Dimensionen und Implikationen der Georgienkrise," Osteuropa, 58, 12:65-80, 2008.

Halbach, Uwe, "'Georgienkrise' und 'Kaukasuskonflikt': Die regionale Dimension des neuerlichen Kriegs im Südkaukasus," Europäisches Journal für Minderheitenfragen, 2, 1:4-19, April 2009.

Hooghe, Liesbet and Gary Marks, "Calculation, Community and Cues: Public Opinion on European Integration," European Union Politics, 6, 4:419-443, December 2005.

Hosmer, David and Stanley Lemeshow, Applied Logistic Regression. New York: Wiley, 2000.

IMF (International Monetary Fund), World Economic Outlook Database, Washington DC, 2010.

Jacobs, Jörg and Detlef Pollack, "Support Based on Values? Attitudes toward the EU in Eleven Postcommunist Societies," in Robert Rohrschneider and Stephen Whitefield, eds., Public Opinion, Party Competition, and the European Union in Post-Communist Europe. New York: Palgrave Macmillan, 2006.

Kostadinova, Valentina, "The Commission, ENP and Construction of Borders," Geopolitics, 14, 2:235-255, 2009.

Lapidus, Gail, "Between Assertiveness and Insecurity: Russian Elite Attitudes and the Russia-Georgia Crisis," Post-Soviet Affairs, 23, 2:138-155, April-June 2007.

Munro, Neil, "Which Way Does Ukraine Face? Popular Orientations Towards Russia and Western Europe," Problems of Post-Communism, 54, 6:43-58, November-December 2007.

Nagelkerke, Nico J. D., "A Note on a General Definition of the Coefficient of Determination," Biometrika, 78, 3:691-692, September 1991.

Papava, Vladimer and Michael Tokmazishvili, "Becoming European: Georgia's Strategy for Joining the European Union," Problems of Post-Communism, 53, 1:26-32, January-February 2006.

Pop, Valentina, "EU Expanding Its 'Sphere of Influence,' Russia Says," EU Observer, March 21, 2009, available at http:/ / euobserver.com/9/27827.

Rohrschneider, Robert and Stephen Whitefield, "Political Parties, Public Opinion and European Integration in Post-Communist Countries: The State of the Art," European Union Politics, 7, 1:141-160, March 2006.

Rose, Richard and Neil Munro, "Do Russians See Their Future in Europe or the CIS?," Europe-Asia Studies, 60, 1:49-66, January 2008.

Saakashvili, Mikheil, "Inaugural Address," Tbilisi, January 25, 2004, formerly available on the website of the President of Georgia. 
Sergunin, Alexander A., "EU and Russia: An Eastern Partnership Muddling On?," Open Democracy, January 28, 2010, available at www.opendemocracy.net/od-russia/ alexander-sergunin/eu-and-russia-eastern-partnership-muddling-on.

Statistical Yearbook of Georgia. Tbilisi: Ministry of Economic Development of Georgia, 2007.

Svensson, Therese and Julia Hon, "Attitudes Toward the West in the South Caucasus," Caucasus Analytical Digest, 13:11-15, 2010.

Tucker, Joshua A., Alexander C. Pacek, and Adam J. Berinsky, "Transitional Winners and Losers: Attitudes Toward EU Membership in Post-Communist Countries," American Journal of Political Science, 46, 3:557-571, July 2002.

Valiyev, Anar, "Victim of a 'War of Ideologies': Azerbaijan after the Russia-Georgia War," Demokratizatsiya, 17, 3:269-288, Summer 2009.

Welt, Cory, "Still Staging Democracy: Contestation and Conciliation in Postwar Georgia," Demokratizatsiya, 17, 3:196-226, Summer 2009.

White, Stephen, Julia Korosteleva, and Ian McAllister, "A Wider Europe? The View from Russia, Belarus and Ukraine," JCMS: Journal of Common Market Studies, 46, 2:219-241, March 2008.

White, Stephen, Ian McAllister, and Margot Light, "Enlargement and the New Outsiders," JCMS: Journal of Common Market Studies, 40, 1:135-153, March 2002a.

White, Stephen, Ian McAllister, Margot Light, and John Löwenhardt, "A European or a Slavic Choice? Foreign Policy and Public Attitudes in Post-Soviet Europe," EuropeAsia Studies, 54, 2:181-202, 2002b.

Whitefield, Stephen, Robert Rohrschneider, and Rasa Alisauskiene, "Support for the European Union in the Baltic States," in Robert Rohrschneider and Stephen Whitefield, eds., Public Opinion, Party Competition, and the European Union in PostCommunist Europe. New York: Palgrave Macmillan, 2006.

Whitman, Richard G. and Stefan Wolff, "The EU as a Conflict Manager? The Case of Georgia and Its Implications," International Affairs, 86, 1:87-107, January 2010. 


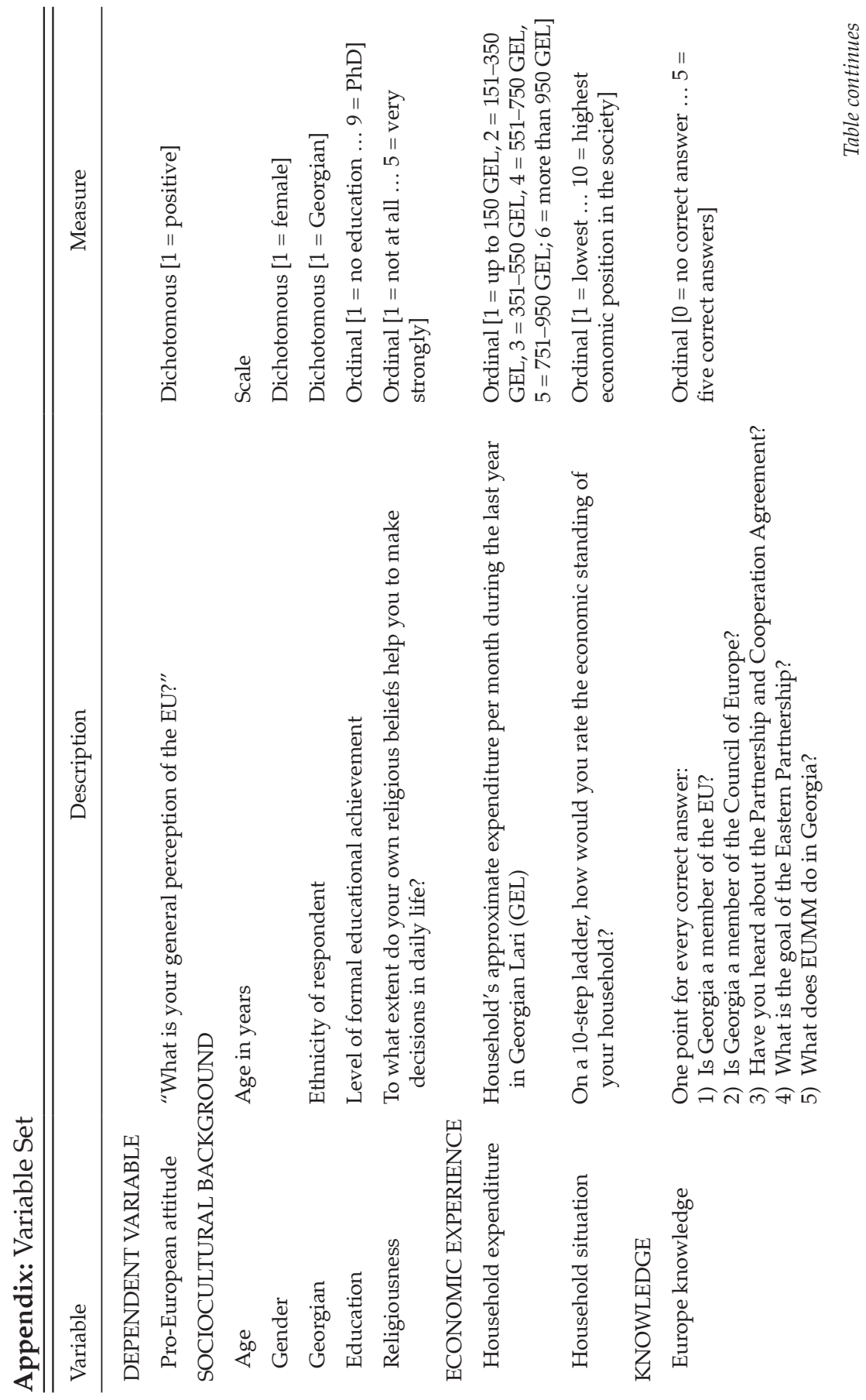



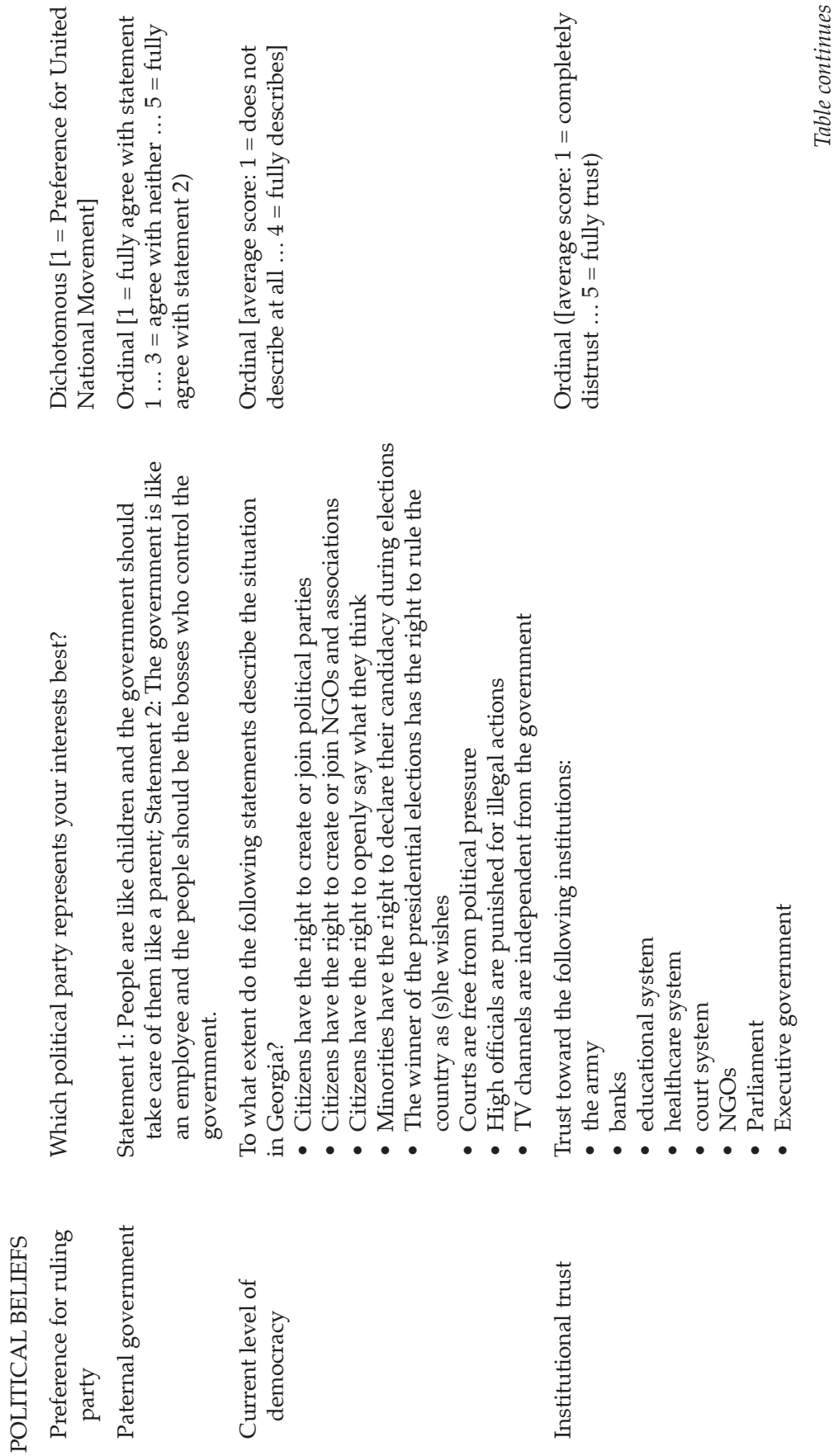


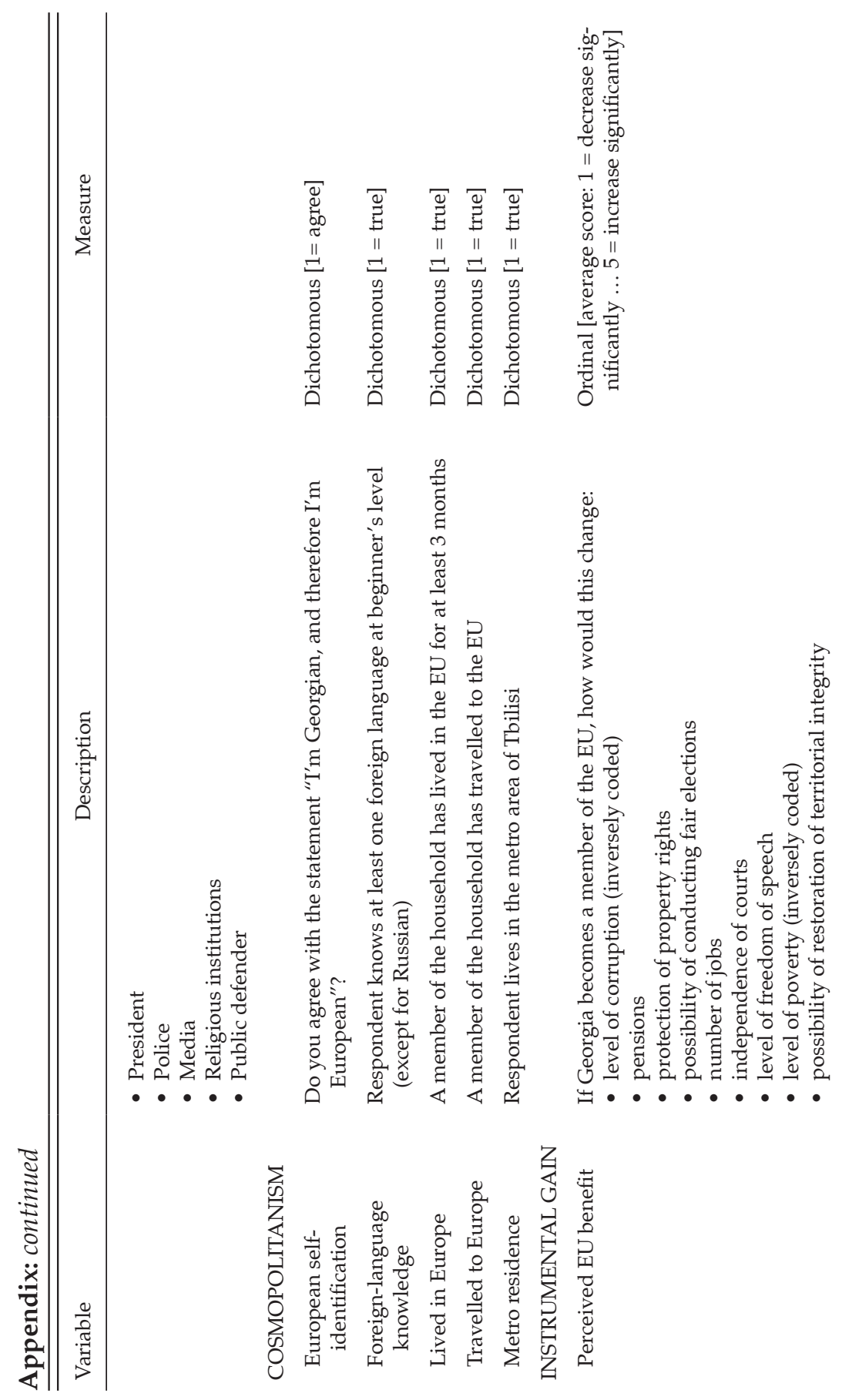



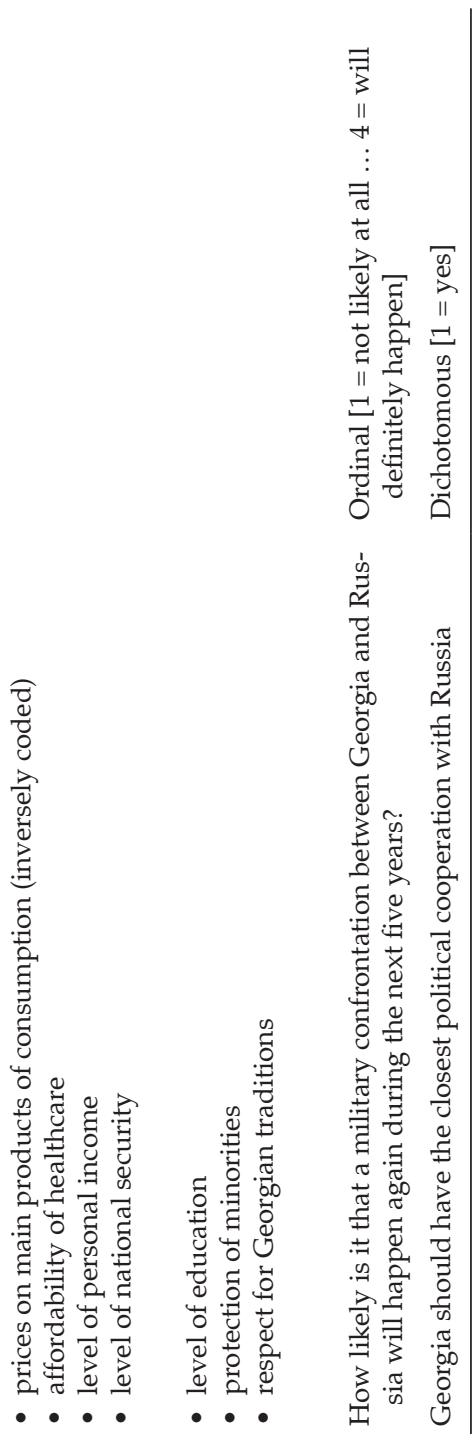

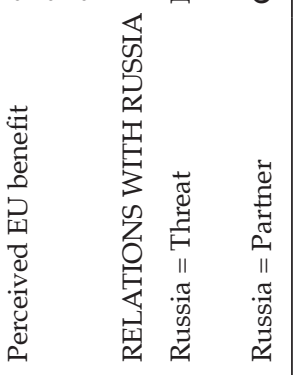




\section{Survey Administration}

The survey was conducted from August 1 to August 10, 2009 by the Caucasus Research Resource Center (CRRC) in Tbilisi and resulted in a sample of 1,886 full interviews from a total of 2,423 contacts (response rate $=$ 77.8 percent). The target population of the survey comprises all Georgianspeaking adult citizens of the Republic of Georgia (excluding Abkhazia and South Ossetia). To draw the sample the country was stratified into three macro-strata (capital, urban, rural) and subsequently 102 clusters were selected throughout the country. Clusters coincided with electoral districts. Households were selected by random route sampling and the respondent within the household was selected using a Kish table. Interviews were conducted face-to-face by trained interviewers in the homes of respondents. Non-response arose primarily from not being able to locate the selected respondent within the survey timeframe.

\section{Data Preparation and Analysis}

For the calculation of descriptive statistics (percentages and means) weights were applied to adjust for non-response and non-coverage. Applying weights did not have any impact on descriptive statistics that exceeded the margin of error. Details of the weighting process can be obtained from the author. Cronbach's $\alpha$ was used to assess the consistency of democracy in Georgia $(\alpha=0.80)$, institutional trust $(\alpha=0.90)$, and EU benefit $(\alpha=$ 0.87 ) as latent variables. For modeling attitude toward the EU a binomial logistic regression model was constructed, since the data did not meet the criteria for parallel lines assumption required for ordinal regression. For the regression, missing values of the predictors were imputed using Maximum Likelihood Estimation. The analysis consists of seven models, entering sets of predictors stepwise, and a parsimonious model containing only variables with statistically significant relationships. Nagelkerke's pseudo- $\mathrm{R}^{2}$ was used to measure the strength of association between the dependent variable and the predictors. Nagelkerke's $R^{2}$ is similar to $R^{2}$ in Ordinary Least Squares Regression (OLS) but in most cases will tend to run somewhat lower (Nagelkerke, 1991). The proportional reduction in error represents the improvement in classifying respondents correctly that is achieved through the model as compared to pure guessing and is another measure of model adequacy. Goodness-of-fit is assessed through the Hosmer and Lemeshow test in which well-fitting models show nonsignificant $\chi^{2}$ values (Hosmer and Lemeshow, 2000). 